\title{
A gyermekkori (0-14 év) 1-es típusú diabetes incidenciájának alakulása Magyarországon (2014-2018). 30 éves a Magyar Gyermekdiabetes Epidemiológiai Hálózat
}

Soltész Gyula dr., Kozári Adrienne dr., Cvenitsné Árkus Ágnes, Stomfai Sarolta dr., Erhardt Éva dr., Rózsai Barnabás dr., Bokor Szilvia dr. és a Magyar Gyermekdiabetes Epidemiológiai Hálózat

összefoglalás

A gyermekkori (0-14 év) 1-es típusú diabetes incidenciája - bizonyos évenkénti fluktuáció mellett - a legutóbbi ötéves periódusban Magyarországon nem változott lényegesen. Az öt év incidenciaátlaga 21,5 (95\%-os Cl: 20,4-22,6)/100000/év volt. Ez más szavakkal azt jelenti, hogy hazánkban évente mintegy 300 új diabeteses gyermek kerül felismerésre. Ebben az idöszakban az incidencia jelentösen különbözött a 6 alcsoportban (0-4,5-9 és 10-14 éves fiúk és leányok). A legmagasabb a 10-14 éves fiúkban, legalacsonyabb pedig a 0-4 éves fiúkban volt, évenkénti ingadozással, szignifikáns változás nélkül. Az elmúlt 30 év alatt az incidencia 9,0/100 000/évröl (1989-1993) 21,5/100000/évre (2014-2018) emelkedett. Ez mintegy $4 \%-o s$ évenkénti növekedésnek felel meg. Az incidencianövekedés üteme azonban nem volt egyenletes, a leggyorsabb (9,8\%/év) 2004 és 2008 között volt, az elmúlt két ötéves periódusban már jelentösen mérséklödött (1,8\% és 1,6\%/év). Az elmúlt három évtizedben minden egyes ötéves periódus incidenciája valamennyi alcsoportban magasabb volt az elözö ötéves idöszak incidenciájánál, egyetlen kivétellel. 2014 és 2018 között elöször figyelhettük meg az incidencia csökkenését, mégpedig a 0-4 éves fiúknál (15,0 vs. 13,5).

Az incidencianövekedés ütemének mérséklödése örvendetes fejlemény, de fontos hangsúlyozni, hogy annak jelenlegi szintje, nemzetközi összehasonlitásban is, igen magas, és a diabeteses gyermekek ellátása jelentös terhelést jelent az érintett családoknak, valamint az egészségügyi rendszernek.

Kulcsszavak: 1-es típusú diabetes, epidemiológia, incidencia, genetikai és környezeti rizikótényezök

The incidence of childhood type 1 diabetes in Hungary (2014-2018). 30 years of the Hungarian Childhood Diabetes Epidemiology Network

Summary: The incidence of childhood type 1 diabetes (0-14 years) in Hungary - with some yearly fluctuations - has not changed significantly over the last five years. The average incidence between 2014 and 2018 was 21.5 195\% Cl: 20.4-22.6)/100,000/year. In other words, approximately 300 new cases were diagnosed in each year. In this period there were large differences in incidence among the six subgroups (0-4,5-9 and 10-14 years, boys and girls). The incidence was highest in the 10-14 old boys and lowest in the 0-4 year old boys. There were no significant changes in incidence in either of the subgroups between 2014 and 2018.

Over the last 30 years the incidence increased from $9.1 / 100,000 /$ year to 21.5/100,000/year. This corresponds to a yearly increase of $4 \%$. The rate of increase, however, was, not uniform. It was fastest (9.8\%/year) between 2004 and 2008 and has slowed down considerably during the last two five year periods (1.8\% and $1.6 \%$, respectively). Over the last 30 years the incidence in every five year period in every subgroup was higher as compared to the incidence of the previous five year period with one notable exception. The incidence in the $0-4$ year boys decreased in the first time between 2014 and 2018 (from 15.0 to 13.5). The levelling off of the incidence is a positive development, but it is to be emphasised, that the present incidence level, in international comparison, is still very high and the management of diabetic children presents a great burden for the families and health services. 
Key words: type 1 diabetes, epidemiology, incidence, genetic and environmental risk factors

A z 1-es típusú diabetes az egyik leggyakoribb krónikus betegség gyermek- és serdülőkorban. Inzulindependens, jelenlegi tudásunk szerint életre szóló, a kezelés költséges és önfegyelmet igényel, pszichoszociálisan és familiárisan is megterhelő, valamint akut és krónikus (késői) szövődmények veszélyével jár.

Az elmúlt évtizedekben számos országban a betegség gyakoribbá válásáról számoltak be, ${ }^{1}$ és a legutóbbi 25 év során (1989-2013) az incidencia hazánkban is jelentős mértékben növekedett. ${ }^{1,2}$

Vizsgálatunkban elsősorban arra a kérdésre kerestünk választ, hogy a közvetlenül magunk mögött hagyott ötéves periódusban (2014-2018) folytatódott-e a negyedszázad óta tartó emelkedési trend. További célkitűzésünk az volt, hogy a harmincéves évforduló alkalmából visszatekintve, elemezzük az elmúlt évtizedek incidenciatrendjeit.

\section{Betegek és módszer}

A Magyar Diabetes Társaság (MDT) és a Magyar Gyermekorvosok Társasága (MGyT) közös Gyermekdiabetes Szekciójának égisze alatt működő Magyar Gyermekdiabetes Epidemiológiai Munkacsoport (a továbbiakban Hálózat) a 0-14 éves, 1-es típusú diabeteses gyermekek diagnózis időpontjában rögzített néhány adatát gyűjti és elemzi. Működése 1989-ben, a hazai gyermekdiabetes-gondozók önkéntes társulásával kezdődött, majd az Egészségügyi Minisztérium „Közös kincsünk a gyermek” Nemzeti Csecsemő- és Gyermekegészségügyi Program (XII/1-3) részeként elrendelte az adatgyűjtést és a Pécsi Gyermekklinikát bízta meg annak irányításával (2005). A Hálózat része a nemzetközi EURODIAB epidemiológiai munkacsoportnak (26 centrum), amely 1999 és 2010 között pécsi irányítással működött $d r$. Soltész Gyula (a Hálózat koordinátora) vezetésével és $d r$. Gyürüs Éva (data manager) közreműködésével. ${ }^{1,2}$

Hazánkban hagyományosan minden újonnan felismert 1-es típusú diabeteses gyermek kezelése kórházi gyermekosztályon kezdődik. Epidemiológiai adatlapunkat - immár három évtizede rutinszerűen - a gyermekosztályokon dolgozó és a diabetesgondozást is ellátó kollégák, illetve munkatársaik töltik ki és juttatják el a koordináló központba.
$\mathrm{Az}$ adatgyüjtésben a diabetes egyéb formáiban (neonatalis diabetes, cisztás fibrózis, kortikoszteroid indukálta diabetes, monogénes diabetes, 2-es típusú diabetes stb.) szenvedő gyermekek nem vettek részt. A monogénes diabeteses gyermekeket utólag zártuk ki az analízisből. Az adatlap néhány demográfiai adatot (név, születési dátum és lakhely), valamint a diagnózist megelőző tüneteket, a diagnózis és az első inzulininjekció időpontját, laboratóriumi vizsgálati eredményeket és a diabetes családon belüli előfordulására vonatkozó kérdést tartalmaz. A továbbiakban az adatok kezelése, elemzése már anonimizált formában történik, ami a betegeket azonosíthatatlanná teszi. A Hálózat nem tekinthető az inzulinpumpa-regiszterhez hasonló betegregiszternek, hiszen a továbbiakban nem követi a betegek sorsának, laboratóriumi és kezelési eredményeinek alakulását.

A jelen közleményünkben csak az incidenciaszámításhoz szükséges demográfiai adatok (életkor, nem és a diagnózis éve) elemzésével foglalkozunk, a további adatok kiértékelése egy külön kézirat tárgyát képezi.

A 2014-2018-as periódus incidenciaadatainak gyűjtésében a 28 magyarországi gyermekdiabetes-gondozó közül 27 vett részt (ezek névsora az Appendixben olvasható). A 2014-2018as periódusban az egri gondozóból nem kaptunk adatokat. A nem Egerben (Budapest és Miskolc) diagnosztizált, de Heves megyében élő gyermekeket az elemzésből kizártuk. Ennek megfelelően az incidenciaszámításban az országos népességszámból a Heves megyei gyermekek számát (az ország gyermeklakosságának 3 százaléka) kivontuk. Elemzésünkben így a fenti időszakban a Magyarországon diagnosztizált diabeteses gyermekek $97 \%$-a vett részt.

$\mathrm{Az}$ adatok kiértékelését rutin statisztikai módszerekkel, illetve a korábbi közleményeinkben részletezett ${ }^{1,2,3}$ elemzésekkel végeztük. Az incidenciát az adott naptári évben regisztrált esetek számának és az ugyanazon év népességszámának (0-14 év) hányadosa adta (új eset/100000 lakos/év). ${ }^{3}$

A népességadatokat a Központi Statisztikai Hivatal bocsátotta rendelkezésünkre.

\section{Eredmények}

$\mathrm{Az}$ 1. táblázat bemutatja az incidencia évenkénti alakulását a legutóbbi ötéves periódusban (2014-2018). Az incidencia évről évre 
történő bizonyos fluktuációja figyelhető meg, lényeges változás nélkül. Az öt év incidenciaátlaga $21,5 \pm 1,1$ volt.

A gyermekek 53,3\%-a fiú, 46,7\%-a leány volt.

$\mathrm{Az}$ átlagéletkor a diagnózis időpontjában 8,6 év volt, a fiúk több mint fél évvel idősebbek voltak (8,9 év) a leányoknál (8,3 év).
A 2. táblázat a kor- és nemspecifikus incidencia évenkénti alakulását mutatja be 2014 és 2018 között. Az incidencia jelentősen különbözött a 6 alcsoportban (0-4, 5-9 és 10-14 éves fiúk és leányok). A legmagasabb a 10-14 éves fiúkban, legalacsonyabb pedig a 0-4 éves fiúkban volt, évenkénti ingadozással, szignifikáns változás nélkül.

1. táblázat. A gyermekkori (0-14 év) 1-es típusú diabetes incidenciájának (új eset/100000 gyermeklakos/év) alakulása (2014-2018)

\begin{tabular}{|c|c|c|c|c|}
\hline $\mathbf{2 0 1 4}$ & $\mathbf{2 0 1 5}$ & $\mathbf{2 0 1 6}$ & $\mathbf{2 0 1 7}$ & $\mathbf{2 0 1 8}$ \\
\hline $21,1 \pm 2,1$ & $19,4 \pm 2,3$ & $22,4 \pm 2,5$ & $22,6 \pm 2,5$ & $21,9 \pm 2,5$ \\
\hline
\end{tabular}

2. táblázat. A gyermekkori (0-14 év) 1-es típusú diabetes kor-és nemspecifikus incidenciájának (új eset/100 000 gyermeklakos/év; átlag \pm SE) évenkénti alakulása (2014-2018)

\begin{tabular}{|c|c|c|c|c|c|c|}
\hline \multirow{2}{*}{} & \multicolumn{4}{|c|}{ Fiúk } & \multicolumn{3}{c|}{ Lányok } \\
\cline { 2 - 7 } & $\mathbf{0 - 4}$ év & $\mathbf{5 - 9}$ év & $\mathbf{1 0 - 1 4}$ év & $\mathbf{0 - 4}$ év & $\mathbf{5 - 9}$ év & $\mathbf{1 0 - 1 4}$ év \\
\hline $\mathbf{2 0 1 4}$ & $12,8 \pm 4,6$ & $25,4 \pm 6,3$ & $28,9 \pm 6,8$ & $12,1 \pm 4,6$ & $23,7 \pm 6,3$ & $22,6 \pm 6,2$ \\
\hline $\mathbf{2 0 1 5}$ & $9,3 \pm 4,0$ & $24,0 \pm 6,1$ & $26,4 \pm 6,5$ & $14,5 \pm 5,1$ & $22,2 \pm 6,0$ & $19,5 \pm 5,8$ \\
\hline $\mathbf{2 0 1 6}$ & $15,9 \pm 5,2$ & $24,7 \pm 6,3$ & $30,8 \pm 7,0$ & $17,2 \pm 5,5$ & $20,3 \pm 5,8$ & $23,4 \pm 6,3$ \\
\hline $\mathbf{2 0 1 7}$ & $13,9 \pm 4,8$ & $25,8 \pm 6,5$ & $28,9 \pm 6,8$ & $14,7 \pm 5,1$ & $31,1 \pm 7,3$ & $20,5 \pm 5,9$ \\
\hline $\mathbf{2 0 1 8}$ & $15,9 \pm 5,1$ & $18,0 \pm 5,4$ & $30,8 \pm 7,0$ & $14,6 \pm 5,4$ & $23,9 \pm 6,4$ & $27,8 \pm 6,8$ \\
\hline $\mathbf{2 0 1 4 - 2 0 1 8}$ & $13,6 \pm 2,1$ & $23,6 \pm 2,7$ & $29,2 \pm 3,1$ & $14,6 \pm 2,3$ & $24,2 \pm 2,9$ & $22,8 \pm 2,8$ \\
\hline
\end{tabular}

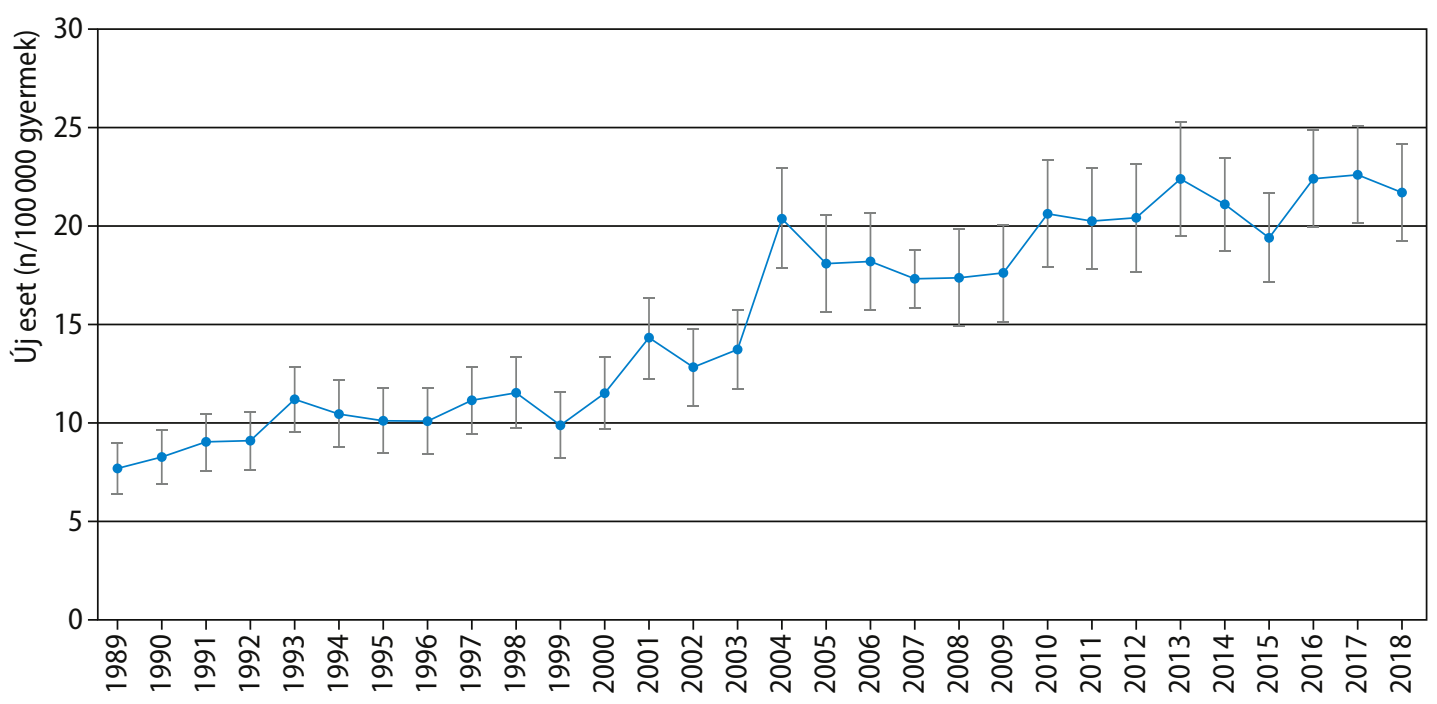

1. ábra. A gyermekkori 1-es típusú diabetes incidenciájának évenkénti alakulása Magyarországon (1989-2018) 
Az 1. ábra, részben már publikált adatok felhasználásával, a teljes 30 éves periódus incidenciájának évenkénti alakulását mutatja be. Az incidencia közel háromszorosára nőtt a három évtized alatt, de a változás nem volt egyenletes, a jelentősebb emelkedés az első másfél évtizedben történt, a legutóbbi években a növekedés üteme nagymértékben lelassult. A 3. táblázatban ugyanez látható ötéves periódusokban. A táblázat első oszlopa demonstrálja, hogy az elmúlt 30 év alatt az incidencia 9,0/100000/évről 21,5/100000/évre emelkedett. Ez mintegy $4 \%$-os évenkénti növekedésnek felel meg. A táblázat második oszlopa bemutatja az incidencia évenkénti százalékos növekedését a megelőző ötéves periódussal összehasonlítva. Látható, hogy a növekedés üteme nem volt egyenletes, a leggyorsabb (9,8\%) 2004 és 2008 között volt, az elmúlt két ötéves periódusban az incidencianövekedés évi üteme már jelentősen mérséklődött (1,8\% és 1,6\%).

$\mathrm{Az}$ elmúlt 30 évben minden egyes ötéves periódus incidenciája valamennyi alcsoportban magasabb volt az előző ötéves időszak incidenciájánál, egyetlen kivétellel. A legutóbbi időszakban, 2014 és 2018 között először figyelhettük meg az incidencia csökkenését, mégpedig a 0-4 éves fiúknál $(15,0$ vs. 13,5$)$.

\section{Megbeszélés}

A gyermekkori 1-es típusú diabetes a múlt század első felében valószínűleg ritka betegség volt., ${ }^{4,5}$ Az incidenciaemelkedés a huszadik század második felében kezdődött. ${ }^{6}$ Erről az egyre szaporodó

3. táblázat. A gyermekkori 1-es típusú diabetes incidenciájának (új eset/100000 gyermek/év, átlag士SE) alakulása Magyarországon (1989-2018) ötéves periódusokban. (Részben a 1. és 2. sz közlemény adatainak felhasználásával készült táblázat)

\begin{tabular}{|c|c|c|} 
& Incidencia & Növekedési ütem (\%/év) \\
\hline $\mathbf{1 9 8 9 - 1 9 9 3}$ & $9,0 \pm 0,3$ & \\
\hline $\mathbf{1 9 9 4 - 1 9 9 8}$ & $10,7 \pm 0,4$ & 3,8 \\
\hline $\mathbf{1 9 9 9 - 2 0 0 3}$ & $12,4 \pm 0,4$ & 3,2 \\
\hline $\mathbf{2 0 0 4 - 2 0 0 8}$ & $18,3 \pm 0,6$ & 9,8 \\
\hline $\mathbf{2 0 0 9 - 2 0 1 3}$ & $20,0 \pm 0,6$ & 1,8 \\
\hline $\mathbf{2 0 1 4 - 2 0 1 8}$ & $\mathbf{2 1 , 5 \pm 0 , 5}$ & 1,6 \\
\hline
\end{tabular}

regionális, országos és nemzetközi regiszterek tudósítottak. ${ }^{7}$ Az incidenciatrendek mellett az is ismertté vált, hogy a gyermekkori 1-es típusú diabetes előfordulásában az egyes földrajzi régiók és országok között igen nagyok a különbségek, amelyek még Európán belül is jelentősek. ${ }^{2} \mathrm{Az}$ incidencia alapján (új eset/100000 gyermek/év) a Nemzetközi Diabetes Szövetség (International Diabetes Federation, IDF) az egyes országokat az alábbi kategóriákba sorolja: igen alacsony $(<5)$, alacsony $(5-9,9)$, közepes $(10-19,9)$, magas $(20-29,9)$ és igen magas $(>30)$ incidenciájú országok. ${ }^{8}$ Hazánk a legutóbbi időszak (2014-2018) incidenciája (21,5) alapján a magas incidenciájú országok közé tartozik. Az elmúlt ötéves időszak 21,5/100000/év incidenciája más szavakkal annyit jelent, hogy hazánkban évente mintegy 300 új diabeteses gyermek kerül felismerésre.

Jelen felfogásunk szerint a gyermekkori 1-es típusú diabetes poligénes, multifaktoriális, autoimmun betegség, amely a genetikailag arra hajlamos egyénekben diabetogén környezeti tényezők hatására alakul ki. A genetikai hátteret számos, hatásában különböző erősségű (gyenge, közepes és erős hatású) gén alkotja. Ezek a gének egymással és a patogén környezeti tényezőkkel is komplex kölcsönhatásban vannak. Feltételezés szerint az incidencia nagy geográfiai variabilitásában mind a genetikai, mind a környezeti tényezők szerepet játszhatnak.

Az elmúlt évtizedekben az incidencia a legtöbb országban, így hazánkban is jelentősen emelkedett, amint azt az 1. ábra és a 3. táblázat adatai mutatják. Az emelkedés üteme nem volt egyenletes, legutóbbi közleményünkben ${ }^{1}$ „csúcsok és fennsíkok" kifejezéssel próbáltuk leírni a jelenséget, egyes országokban négyévenkénti ciklikus változásokat is megfigyeltek. ${ }^{2}$

$\mathrm{Az}$ incidencia emelkedésért minden bizonnyal környezeti tényezők tehetők felelőssé, hiszen nagyon valószínűtlen, hogy a populáció genetikai rizikója ilyen rövid idő alatt jelentősen megváltozzon. A diabetogén környezeti tényezők nagy része még feltáratlan, a jelenleg ismertek (kalóriadús táplálkozás, gyors lineáris növekedés, túlsúly stb.) „gyenge” rizikófaktorok, együttesen is csak egy kis részét magyarázzák az incidenciaemelkedésnek.

Az utóbbi években néhány észak-európai országban, például Norvégiában az incidencianövekedés megtorpanásáról tudósítottak. ${ }^{9}$ Legújabban pedig az amerikai Alabama államban végzett felmérés 
szerint 2007 és 2017 között az incidencia évenkénti üteme $1,7 \%$-kal csökkent. ${ }^{10}$ Hazánkban is lassuló tendenciát figyelhettünk meg a legutóbbi két ötéves periódus során. Ezen jelenség oka nem ismert. Feltételezik, hogy létezik egy úgynevezett maximális incidencia, amit elsősorban a genetikai rizikófaktorok határoznának meg, és egyes magas incidenciájú országok/populációk közelítenek ehhez a maximumhoz, vagy esetleg már el is érték azt. ${ }^{7}$

$\mathrm{Az}$ incidencianövekedés ütemének hazai mérséklődése örvendetes fejlemény, de fontos hangsúlyozni, hogy az incidencia jelenlegi szintje nemzetközi összehasonlításban is igen magas, és a diabeteses gyermekek ellátása számottevő terhelést jelent mind az érintett családoknak, mind az egészségügyi rendszernek.

\section{Köszönetnyilvánítás}

Hálásan köszönjük Chris Patterson biostatisztikus/epidemiológus professzor (Queen's University Belfast) hasznos tanácsait.

Köszönetet mondunk Molnár Györgyné főtanácsosnak, a KSH munkatársának a részletes és naprakész népességadatokért, valamint a gyermekdiabetes-gondozók munkatársainak több évtizedes segítő munkájukért.

\section{Appendix}

A Magyar Gyermekdiabetes Epidemiológiai Hálózat adatszolgáltató kollégái és szakdolgozói (munkahelyek szerint, a nevek alfabetikus sorrendben):

- Budapest, SE, I. Gyermekklinika: dr. Körner Anna, dr. Luczay Andrea, dr. Madácsy László, Palikné Szabó Katalin, Szilvágyi Márta, dr. Tóth-Heyn Péter

- Budapest, SE, II. Gyermekklinika: $d r$. Gács Zsófia, dr. Hosszú Éva, dr. Török Dóra

- Budapest, Heim Pál Kórház: dr. Almássy Zsuzsa

- Budapest, Szent János Kórház: dr. Blatniczky László, Szabó Gabriella

- Budapest, Flór Ferenc Kórház: dr. Blatniczky László

- Budapest, Bethesda Kórház: dr. Aichert Gabriella, dr. Bihari Krisztina, dr. Szabó Ildikó
- Pécs: dr. Bokor Szilvia, Czvenitsné Árkus Ágnes, dr. Erhardt Éva, dr. Kozári Adrienne, dr. Stomfai Sarolta

- Kecskemét: dr. Góg Erzsébet, Tót-Koncsor Krisztina

- Kiskunhalas: dr. Balázsik Andrea

- Baja: dr. Trója Tünde

- Gyula: dr. H. Nagy Katalin, Seresné Szabó Ágnes

- Miskolc: dr. Barkai László, Bartkóné Kovács Anett, dr. Soós Andrea, dr. Török András

- Szeged: dr. Gellén Balázs, dr. Kürti Kálmán, $d r$. Maróti Ágnes, dr. Román Rita

- Hódmezővásárhely: dr. Hocsi Mária, dr. Szüts Péter

- Székesfehérvár: dr. Karádi Zsuzsanna, Szabóné Hajdú Ildikó

- Győr: dr. Gál Veronika, Juhászné Tuifel Andrea, dr. Niederland Tamás, Sebestyén Tímea

- Sopron: dr. Gelencsér Éva

- Debrecen: dr. Felszeghy Enikö, dr. Juhász Éva

- Komárom: dr. Kocsis Katalin

- Salgótarján: Gordos Livia, dr. Török András

- Kaposvár: dr. Bátori Bea, dr. Dósa Magdolna

- Nyíregyháza: dr. Kántor Irén

- Szolnok: Kátainé Fülöp Éva, dr. Ragó Márta, dr. Retkes Tamás

- Szekszárd: Kutasi Ildikó, dr. Rippl Ilona

- Szombathely: dr. Balogh Márta, dr. Csákvári Krisztina, dr. Margarics Éva

- Veszprém: dr. Bertalan Rita, dr. Gajzer Éva, Hegedüs Gyuláné, Nagyné Orbán Andrea, dr. Soós Hajnalka, Timkó Bernadett

- Zalaegerszeg: dr. Buzogány Mária 


\section{rodalom}

1. Gyürüs E, Patterson CC, Soltész Gy és a Magyar Gyermekdiabetes Epidemiológiai Munkacsoport: „Folyamatos emelkedő vagy csúcsok és fennsikok?" A gyermekkori 1-es típusú diabetes incidenciája Magyarországon (1989-2009). Orvosi Hetilap 2011; 152: 1690-1695.

2. Patterson CC, Harjutsalo V, Rosenbauer J, Neu A, Cinek O, Skrivarhaug $\mathrm{T}$, et al.: Trends and cyclical variation in the incidence of childhood type 1 diabetes in 26 European centres in the 25 year period 1989-2013: a multicentre prospective registration study. Diabetologia 2019; 62: 408-417. doi:10.1007/s00125-018-4763-3

3. Ahlblom A, Norell S: Introduction to modern epidemiology. Epidemiology Resources Inc., 1984. Chapter 9. pp. 63-65.

4. Fejes I: A cukorbajos gyermekek sorsa. A Pécsi M. Kir. Erzsébet Tudományegyetem Gyermekklinikájának kiadványai. Rákóczi Nyomda, Pécs, 1941. december.

5. Gegesi Kiss P. Barta L: Diabetes mellitus a csecsemö- és gyermekkorban. Múvelt Nép, 1956. p. 84

6. Gale, EAM: The rise of childhood type1 diabetes in the 20th century. Diabetes 2002; 51: 3353-3361. doi:10.2337/diabetes.51.12.3353

7. Lawrence, JM, Mayer-Davis EJ: What do we know about the trends in incidence of childhood-onset type 1 diabetes? Diabetologia 2019; 62: 370-372. doi:10.1007/s00125-018-4791-z
8. Patterson CC, Karuranga S, Salpea P, Saeedi P, Dahlquist G, Soltesz G, et al: IDF Diabetes Atlas 9th edition - Worldwide estimates of incidence, prevalence and mortality of type 1 diabetes in children and adolescents. Diabetes Res Clin Pract 2019. doi:10.1016/j.diabres.2019.107842

9. Skrivarhaug T, Stene LC, Drivvoll AK, Strom H, Joner G: Norwegian Childhood Diabetes Study Group: Incidence of type Idiabetes in Norway among children aged 0-14 years between 1989 and 2012: has the incidence stopped rising? Results from the Norwegian Childhood Diabetes Registry. Diabetologia 2014; 57: 57-62. doi:10.1007/s00125-013-3090-y

10. Correya TA, Ashraf AP, Griffin, Aslibekyan S, Kim HD, Middleton S, et al:: Temporal trends in Incidence of pediatric type 1 diabetes in Alabama: 2000 2017. Pediatric Diabetes (megjelenés alatt), doi:10.1111/pedi.12927

Közlésre érkezett: 2019, november 11.

Közlésre elfogadva: 2019. november 29.

\section{A levelezésért felelős szerző:}

Prof. dr. Soltész Gyula

Pécsi Tudományegyetem, Gyermekklinika 7623 Pécs, József Attila u. 7.

E-mail: soltesz.gyula@pte.hu 